\title{
The SuPREMe COURT, FunCTIONAL BiLINGUALiSM, AND THE INDIGENOUS CANDIDATE: RECONCILING THE BENCH
}

\begin{abstract}
ALEXANDREA NASAGER ${ }^{*}$
The recent reforms to the Supreme Court of Canada appointment process have created potential barriers to Indigenous candidates. This article reviews the appointment process and its two objectives of functional bilingualism and increased diversity. Given the lack of progress on diversity, particularly with respect to Indigenous representation, a rebalancing of appointment criteria is required. Reconciliation, in both the legal and evolving public policy sense, requires Indigenous participation in legal institutions. Furthermore, arguments in favour of functional bilingualism, such as specific legal expertise and incorporation of distinct cultural viewpoints, transfer seamlessly to Indigenous and other minority representation at the Supreme Court. The functional bilingualism requirement should remain, but accommodation for Indigenous candidates is integral to reconciliation.
\end{abstract}

\section{TABLE OF CONTENTS}

I. INTRODUCTION . . . . . . . . . . . . . . . . . . . . . . . 797

II. The Supreme Court of CANAdA ApPointment Process

AND FUnCTIONAL BILINGUALISM . . . . . . . . . . . . . . . . . . . . . . . . . 799

A. BACKGROUND . . . . . . . . . . . . . . . . . . . . . 799

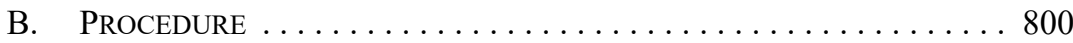

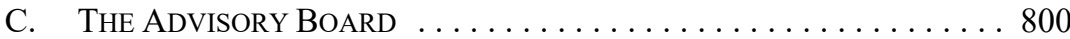

D. The Standard of Functional BilinguAlism $\ldots \ldots \ldots \ldots$. . . . 801

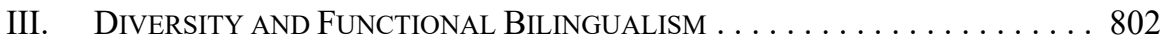

A. The Standard of Diversity $\ldots \ldots \ldots \ldots \ldots \ldots \ldots \ldots \ldots \ldots$

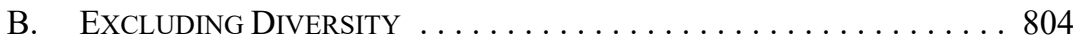

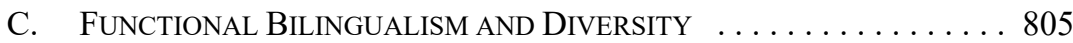

IV. THE IMPOSITION OF FunCTIONAL BiLINGUALISM . . . . . . . . . . . . . . 807

A. RECONCILIATION . . . . . . . . . . . . . . . . . 807

B. SUPPORT FOR FunCTIONAL BILINGUALISM $\ldots \ldots \ldots \ldots 10$

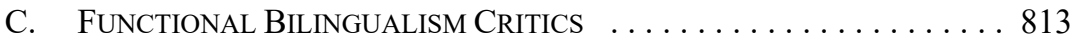

V. ANALYSIS AND RECOMMENDATIONS ... . . . . . . . . . . . . . . 814

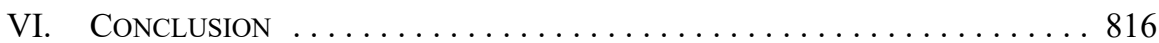

\section{INTRODUCTION}

Canada has yet to appoint an Indigenous ${ }^{1}$ judge to the Supreme Court of Canada. "Since 1875 there has been a requirement that a certain number of seats on the Supreme Court be

Alexandrea Nasager holds an Honours degree in Indigenous Studies from Trent University and a Juris Doctor from the University of Saskatchewan. The focus of her research and advocacy is on Aboriginal law, policy, and governance. She lives and works in the Yukon and is an Indigenous rights activist committed to decolonizing the legal academy and legal profession. She would like to thank Professors Dwight Newman and Felix Hoehn for their mentorship, and Jonathan Ostrander.

1 The term "Indigenous" includes "Status" and "Non-Status Indians," "Inuit," and "Métis" peoples of Canada. "Indigenous" is transferable with the term of art "Aboriginal." "Indigenous" is used for general reference, and "Aboriginal" means "Indigenous" as it applies in the Canadian legal context as per section 35 of the Constitution Act, 1982, s 35, being Schedule B to the Canada Act 1982 (UK), 1982, c 11. 
reserved for Quebec. There is no equivalent requirement that any seats on the Supreme Court be reserved for Indigenous people."2

Recent reforms to the Supreme Court appointment process have prompted a national conversation about the new functional bilingualism and diversity requirements. It is the potential barriers created by these reforms as they effect an otherwise qualified and competent Indigenous judge that are the focus of this article, and the national conversation includes critics who consider the requirements exclusionary.

Canada is a country that boasts two official languages, English and French, ${ }^{3}$ yet Canada's Supreme Court Act ${ }^{4}$ does not statutorily require Supreme Court judges to speak both French and English. ${ }^{5}$ While justices currently serving at the Supreme Court are not required to be functionally bilingual, in August of 2016, Prime Minister Justin Trudeau announced that a new Advisory Board (the Board) would only consider candidates who were functionally bilingual and representative of Canada's diversity. ${ }^{6}$

This article is divided into three substantive parts. Part II of this analysis will study the reorganization of Canada's Supreme Court appointment selection process, familiarize functional bilingualism and the Board, and review the standard of bilingualism now required by the appointment selection process. In Part III, the diversity objective, the second requirement added to the 2016 reforms, will be examined. On its face, the functional bilingualism requirement appears to be harmonious with the objective of the personal and institutional diversity requirements found in the Board's Terms of Reference ${ }^{7}$ and Qualifications and Assessment Criteria. ${ }^{8}$ However, functional bilingualism and diversity, when read together, may raise some internal contradictions that will be identified in Part III.

Part IV of the article contemplates the functional bilingualism requirement, but not to evaluate the reality that Indigenous persons in Canada likely have a lower rate of EnglishFrench bilingualism than others. The greater societal concern is that this requirement may

Bruce McIvor, First Peoples Law: Essays on Canadian Law and Colonization, 3rd ed (2018) at 137, online: <firstpeopleslaw.com/database/files/library/FPL_2018_3RDEd_Download.pdf > .

Official Languages Act, RSC 1985, c 31 (4th Supp), s 2.

RSC 1985, c S-26 [SCA].

Matthew Shoemaker, "Bilingualism and Bijuralism at the Supreme Court of Canada" (2012) 35:2 Can Parliamentary Rev 30 at 30 :

Section 5 of the Supreme Court Act states "Any person may be appointed a judge who is or has been a judge of a superior court of a province or a barrister or advocate of at least ten years standing at the bar of a province." Other than a legislated requirement for three judges to be members of the Quebec Bar, there are no other qualifications. In June 2008, Bill C-559 was introduced by Yvon Godin, MP for Acadie-Bathurst. It required that candidates for the Supreme Court may be appointed only if he or she understands French and English without the assistance of an interpreter. Although the Bill did not become law, this article shows that bilingualism for the Court is a highly controversial topic.

6 Jennifer Pritchett, "SCC Selection Process and the Question of Bilingualism for Indigenous People," AdvocateDaily (2019), online: <advocatedaily.com/suzanne-deliscar-scc-selection-process-and-thequestion-of-bilingualism-for-indigenous-people.html $>$. The function of this article is not to evaluate the worthiness of the new Advisory Board, or the appointment reforms generally. This analysis strictly seeks to examine the functional bilingualism and diversity requirements by engaging a primarily exploratory methodology.

Office of the Commissioner for Federal Judicial Affairs Canada, "Terms of Reference of the Advisory Board"(2019), online: $<$ fja-cmf.gc.ca/scc-csc/2019/mandate-mandat-eng.html $>$ ["Terms of Reference"]. Office of the Commissioner for Federal Judicial Affairs Canada, "Qualifications and Assessment Criteria," online: SCC Appointments <fja-cmf.gc.ca/scc-csc/2019/qualifications-eng.html > ["Qualifications"]. 
be inconsistent with the principles of Indigenous-Canadian reconciliation, with the understanding that reconciliation in its crudest form insists on the recognition, adoption, and accommodation of both non-Indigenous and Indigenous perspectives.

Part IV also draws heavily on arguments from proponents of the reforms to identify the deficiencies of bilingual competence currently at the Supreme Court, separate and apart from the critiques about functional bilingualism from Indigenous opponents. The supporters reinforce the broader idea that there needs to be some accommodation for members of the Supreme Court expected to meet the functional bilingualism standard. Part IV concludes by addressing arguments from Indigenous critics regarding functional bilingualism. The critiques in Part IV are intended to explore the question: is the criterion for selecting Canada's Supreme Court justices inclusive to Indigenous candidates under the diversity objectives; or, in the alternative, do the requirements concurrently gloss over any colonial barriers to those same applicants under the functional bilingualism prerequisite?

Part $\mathrm{V}$ of the article offers some original analysis and recommendations before the conclusion including the ideas that reconciliation requires the accommodation of difference and the qualifications of a unilingual or Indigenous-English bilingually competent applicant should qualify otherwise eligible Indigenous applicants. The functional bilingualism prerequisite to be considered for an appointment to the Supreme Court may, without any discernable flexibility or built-in accommodation, exclude Indigenous candidates from serving on Canada's highest Court notwithstanding the requirement's general legal and political consistency with Canada's two official languages.

\section{The Supreme Court of Canada Appointment Process AND FUNCTIONAL BILINGUALISM}

\section{A. BACKGROUND}

Generally, one third of the cases that come to the Supreme Court of Canada come from the province of Quebec. ${ }^{9}$ In 2009, 22 of the 62 cases heard at the Supreme Court were argued partly or entirely in French from Quebec and other provinces. ${ }^{10}$ At the Supreme Court, a justice who does not read French has to depend on a bench memo typically drafted by a bilingual clerk. ${ }^{11}$ More broadly, the Canadian Charter of Rights and Freedoms ${ }^{12}$ recognizes Canada's official languages, and section 133 of the Constitution Act, $1867^{13}$ guarantees that both English and French can be used "in any Pleading or Process" before the courts of Canada. ${ }^{14}$

Graham Fraser, "In Defence of a Bilingual Supreme Court: Graham Fraser, Canada's Commissioner of Official Languages, on Why Trudeau's Policy on Bilingualism on the Supreme Court Just Makes Sense," Maclean's (2 August 2016), online: <macleans.ca/politics/ottawa/in-defence-of-a-bilingualsupreme-court>.

10 Sébastien Grammond \& Mark Power, "Should Supreme Court Judges Be Required to Be Bilingual?" (2011) Queen's University Institute of Intergovernmental Relations Working Paper No 2011-02 at 3 (it is crucial to recognize that all of the comments provided by Justice Sébastien Grammond in this analysis were made prior to Justice Grammond becoming a Federal Court justice).

Ibid.

12 Part I of the Constitution Act, 1982, being Schedule B to the Canada Act 1982 (UK), 1982, c 11 [Charter].

(UK), 30 \& 31 Vict, c 3, s 133, reprinted in RSC 1985, Appendix II, No 5. Ibid. 
Section 14 of the Charter provides the legal right to access the assistance of an interpreter during judicial proceedings to anyone "who does not understand or speak the language in which the proceedings are conducted or who is deaf." 15 Section 16 of the Charter safeguards English and French as the official languages of Canada and New Brunswick, and includes the principle, "to advance the equality of status or use of English and French."16 Section 19 establishes that either English or French may be used by any person in, or in any pleading or process issuing from, any court established by Parliament. ${ }^{17}$ As of 2016, the Board is the dominant body facilitating and adjudicating these constitutionally sound - but potentially exclusionary — requirements in the appointment process, and plays a significant procedural role in the reforms.

\section{B. PROCEDURE}

The procedural framework of the reforms provides that the SCA legislates the criteria for appointments to the Supreme Court; the Office of the Commissioner for Federal Judicial Affairs (OCFJA) receives applications, and the Board, after consulting with the Chief Justice of the Supreme Court and other stakeholders, makes its recommendations. ${ }^{18}$ The Board will provide the Prime Minister with "non-binding, merit-based recommendations of three to five qualified and functionally bilingual candidates for consideration.",19

The Board will produce an assessment of each candidate's ability to meet the publicly available statutory criteria, and the Justice Minister consults with the Chief Justice of Canada, provincial and territorial Attorneys General, Cabinet Ministers, opposition members of the House of Commons Standing Committee on Justice and Human Rights, and the Standing Senate Committee on Legal and Constitutional Affairs. ${ }^{20}$ The centrality of the Board in the 2016 reforms merits further consideration beyond their procedural functions.

\section{THE AdVISORY BOARD}

The creation of an independent and non-partisan seven-member Board tasked with assessing applications and providing a list of candidates to Prime Minister Trudeau is essential to the new amendments. ${ }^{21}$ The members of the Board represent "the judiciary, the legal profession, the academy, and the public," and the Minister of Justice also "nominates three public members, two of whom are from outside the legal community." 22 The membership of the Board should ensure that "diverse perspectives are brought to bear on the ultimate goal of identifying the best candidates." 23

\footnotetext{
Supra note 12 , s 14 .

Ibid, s 16(3).

Ibid, s 19.

Government of Canada, "New Process for Judicial Appointments to the Supreme Court of Canada" (2 August 2016), online: <pm.gc.ca/eng/news/backgrounders/2016/08/02/new-process-judicial-appoint ments-supreme-court-canada>.

Ibid.

Ibid.

"Terms of Reference," supra note 7.

Rosemary Cairns Way, "Reforming Judicial Appointments: Change and Challenge" (2017) 68 UNBLJ 18 at 23.

Ibid, citing “Terms of Reference," supra note 7.
} 
The Board is required to make recommendations of no less than three, and no more than five candidates who otherwise support the government's intent to achieve a gender-balanced Supreme Court that reflects the diversity of Canadian society, and each of whom is functionally bilingual. ${ }^{24}$ The Minister of Justice presents recommendations to the Prime Minister, who ultimately decides the nominee. ${ }^{25}$

To be clear, prior to August 2016, the Prime Minister would independently nominate any Superior Court Judge or lawyer in accordance with the $S C A^{26}$ and the Constitution Act, $1867^{27}$ for an appointment to the Supreme Court of Canada. Now, according to the Canadian Federal Government, the cornerstone of these reforms are changes intended to strengthen the role of "Judicial Advisory Committees" 28 in the appointment process. Notwithstanding the procedural functions or centrality of the Board, functional bilingualism is arguably the most contentious requirement of the appointment process reforms and accordingly, the scope and content of functional bilingualism is examined in detail below.

\section{The Standard OF FunCtional BILINGUALISM}

At the Supreme Court, justices may ask questions in English or French, and counsel appearing at the Supreme Court may also present oral and written materials in the official language of their choice. ${ }^{29}$ The prerequisite of functional bilingualism imposes that a Supreme Court appointee will read legal materials and understand oral arguments without the need for translation or interpretation, thereby establishing a new standard of fluency where the successful appointee can independently converse with counsel during oral arguments and with other justices in French or English. ${ }^{30}$ The Federal Government has committed to restricting appointments to only those who meet this high threshold of functional bilingualism. ${ }^{31}$ The individuals who compose the pool of functionally bilingual candidates, in addition, must also reflect the diversity of the Canadian population, including members from linguistic minorities; ${ }^{32}$ this will be addressed in further detail in Part III.

The OCFJA has developed a three-part evaluation to assess each component of functional bilingualism based on the OCFJA and the Board's expertise in language training for federally appointed justices. ${ }^{33}$ "A scale of competencies and measurable performance indicators and

Cairns Way, supra note 22.

"Terms of Reference," supra note 7 (the short list of candidates from the Board does not bind the Prime Minister).

Supra note 4, ss 5-6.

Supra note 13.

Department of Justice, News Release, "The Government of Canada Announces Judicial Appointments in the Province of British Columbia" (17 June 2016), online: <canada.ca/en/department-justice/ news/2016/06/the-government-of-canada-announces-judicial-appointments-in-the-province-of-britishcolumbia.html $>$; Cairns Way, supra note 22 at 24.

29 Independent Advisory Board for Supreme Court of Canada Judicial Appointments, Report of the Independent Advisory Board for Supreme Court of Canada Judicial Appointments (August -September 2016) (2016), online: <fja-cmf.gc.ca/scc-csc/2016-MalcolmRowe/mrowe-report-rapport-eng.html\# bm17>.

Ibid.

"Qualifications," supra note 8.

Library of Parliament, Bilingualism in Canada's Court System: The Role of the Federal Government, by Marie-Ève Hudon, Publication No. 2017-33E (Ottawa: Legal and Social Affairs Division, 2017), online: <lop.parl.ca/sites/PublicWebsite/default/en_CA/ResearchPublications/201733E\#txt26>.

Independent Advisory Board for Supreme Court of Canada Judicial Appointments, Report on 2017 Process (2018), online: $<$ fja-cmf.gc.ca/scc-csc/2017-SheilahMartin/smartin-report-rapport-eng. $=\mathrm{html} \#$ bm19> ["Report of the Independent Advisory Board"]. 
corresponding rating guides were set for each of the three abilities. The entire assessment was timed to last 1 hour per candidate." 34 The functional bilingualism test requires candidates to: first, read a legal text followed by comprehension questions in their second official language; second, read a legal pleading in one official language, followed by comprehension questions in the other; and third, be assessed on their ability to converse and interact fluently on diverse subjects, including legal issues in their second language. ${ }^{35}$ In addition, a minimum score of three points out of five is required for candidates to meet the functional bilingualism criteria. $^{36}$

Arguably, the standard required to be functionally bilingual reflects Prime Minister Trudeau's intention to demonstrate an ideal. Supreme Court nominees are now being selected for more than their political views when functional bilingualism operates as a merit-based requirement ensuring Canada's two official languages will have uniformity in status, theory, and application. ${ }^{37}$ In the alternative, because functional bilingualism is not the only new requirement in the 2016 reforms, this underlying merit-based intention is not explicitly obvious. "[T] he requirement of functional bilingualism may well require governments to make difficult trade-offs between bilingualism, excellence, and other forms of diversity." 38

The functional bilingualism and diversity requirements appear to be consistent with principles of Canadian constitutional law in that they are aligned with the promotion, availability, and access to the two official languages in the courts. Nevertheless, with respect to the focus of this analysis, restraints imposed on Indigenous applicants because of the 2016 reforms to the appointment process are not as straightforward. What is problematic, according to Indigenous opponents of the reforms, is what the requirements in their totality omit.

When the ostensibly innocuous functional bilingualism requirement is considered together with the objective of diversity, the second directive of the reforms - the need for cultural and gender equality balanced against the language proficiency threshold - may be jeopardized. Some of the most arguably diverse candidates may be alienated from the Supreme Court selection process. This suggests there are live and internal complexities in the interplay between functional bilingualism and personal and institutional diversity objectives; as such, Part III investigates these issues.

\section{DiVERSity AND FunCTIONAL BILINGUALISM}

If the Board accepts that a candidate has met the functional bilingualism standard, the candidate must also, as a prerequisite, be representative of the diversity of Canada. As this article has shown, the Board is central to the Supreme Court of Canada appointment reforms. "The ... Board must be guided by two institutional criteria: the Supreme Court should be University of Alberta Faculty of Law Blog < ualbertalaw.typepad.com/faculty/2016/11/supreme-court-ofcanada-appoint ments.html>.

Cairns Way, supra note 22 at 25. 
'gender balanced' and 'reflect the diversity of Canadian society." "39 "[A]ppointments should reflect the diversity of the population without sacrificing legal excellence." ${ }^{40}$ Section $8(\mathrm{f})$ of the Board's "Terms of Reference" necessitate a commitment to achieving a gender-balanced Supreme Court of Canada bench inclusive to: "Indigenous peoples, persons with disabilities and members of linguistic, ethnic and other minority communities including those whose members' gender identity or sexual orientation differs from that of the majority." ${ }^{11}$

The Board's Qualification and Assessment Criteria break down broadly into three areas: personal skills and experience, personal qualities, and the institutional needs of the court. ${ }^{42}$ The diversity requirement crudely suggests that if nothing else, the Prime Minister wants Canada's Supreme Court to mirror the country's diverse population. On a deeper investigation of what satisfies a "diverse candidate," the personal and institutional criteria mandated by the 2016 reforms show very little tangible deference to Indigenous applicants, despite that group's prima facie fulfilment of the diversity requirement.

The 2016 criteria specifically identify Indigenous applicants as members of this soughtafter diverse group yet, simultaneously, omits any acknowledgment of colonialism as a barrier that would presumably affect that applicant's ability to meet other personal or institutional criteria with respect to: access to formal education, language training, and opportunities to participate in the judiciary generally. Part IV will address this critique in more detail. As Part II provided a comprehensive account of the standard of functional bilingualism expected from successful applicants, a delineated account of the diversity standard to be met is equally necessary.

\section{A. The STANDARD OF Diversity}

According to the OCFJA's list of "diversity" qualifications, candidates must be alert to and synthesize information about the social context that legal disputes arise in, and be sensitive to changes in social values with respect to the cases that come before the Court. ${ }^{43}$ Supreme Court appointment hopefuls must have an appreciation of "a diversity of views, perspectives and life experiences, including those relating to groups historically disadvantaged in Canadian society." ${ }^{\prime 4}$

At an institutional level, the diversity criteria are attempting to ensure that members of the Supreme Court of Canada reasonably reflect the diversity of Canadian society. ${ }^{45}$ The added complication of regional conventions colours the additional requirements to be met that go beyond the kind of diversity referenced in this article, and it is accepted that these impact the judges represented province to province.

Peter H Russell, “Selecting Supreme Court Justices: Is Trudeau's Sunny Way a Better Way?” (2017) 68 UNBLJ 3 at 10, citing "Terms of Reference," supra note 7, s 8(f).

David Butt, "French Proficiency Shouldn’t Be Mandatory for Canada's Supreme Court Judges," Globe and Mail (10 December 2018), online: <theglobeandmail.com/opinion/article-french-proficiencyshouldnt-be-mandatory-for-canadas-supreme-court>.

Supra note 7, s 8(f).

"Qualifications," supra note 8.

Ibid under heading: "Personal Skills and Experience."

Ibid under heading: "Personal Qualities."

Ibid under heading: "Institutional Needs of the Court." 
While establishing a court that is visibly reflective of Canadian diversity may theoretically ensure that the court can benefit from a range of viewpoints and perspectives, the requirement offers little to recognize and accommodate any colonial barriers that in the first instance present a challenge to members of the diverse class of candidates who may otherwise meet the aforementioned criterion.

For example, between 14 July 2017 to 15 September 2017, 14 diverse jurists applied to become appointed to the Supreme Court of Canada. ${ }^{46}$ Of the applicants in 2016, four were Indigenous, three were visible minorities, two were Lesbian Gay Bisexual Transgender Queer Two Spirit (LGBTQ2), two had disabilities, and 12 others self-identified as minorities. ${ }^{47}$ Jody Wilson-Raybould, former Attorney General and former Minister of Veteran Affairs acting in her position as former Justice Minister, declined to say how many jurists in each of these categories were among the ten who were interviewed by the Board, or who comprised the five candidates who made it to the short list the Board presented to Prime Minister Trudeau. ${ }^{48}$

These data suggest diversity requisites do not impose a meaningful duty to increase the participation of Indigenous candidates despite the explicit naming of Indigenous persons as a category of persons included in the diverse group. Some critics will insist that is exactly what the diversity criteria should express, a visible call to Indigenous applicants to serve on the bench of the Supreme Court of Canada. In the alternative, it is important to acknowledge that the lack of transparency with respect to the actual selection of diverse candidates may conversely indicate that the Board is operating with a wide net, asserting their broad discretion. Therefore, it is possible the personal skills and experiences, personal qualities, and institutional needs of the Supreme Court are subject to a discretionary balancing by the Board to reconcile any discrepancies that may arise between ensuring that the standards of functional bilingualism and diversity are both met. However, this lack of transparency from the Board may signal a continuation and a hesitation to accommodate diversity considering Canada's exclusionary past with respect to minority groups and Indigenous peoples.

\section{B. EXCLUDING DIVERSITY}

Canada's historical treatment of Indigenous people, racial minorities, and the LGBTQ2 community signifies that Canada is not immune from the ills of exclusionary thinking. ${ }^{49}$ Notwithstanding Canada's apparent foundation in the ethics of tolerance and accommodation, the diversity requirement in the reforms initially illustrate an attempt to restore substantive equality to the Supreme Court bench. Yet, without imposing any affirmative mechanisms of accommodation for diverse candidates who may have been historically disadvantaged from meeting certain appointment requirements, when combined with the new imposition of functional bilingualism, Chief Justice Beverley McLachlin's

46 "Report of the Independent Advisory Board," supra note 33 at 6.

47 Cristin Schmitz, "Ontarians Led 31 Hopefuls for SCC Spot," The Lawyers Daily (26 January 2017), online: <thelawyersdaily.ca/articles/3436/ontarians-led-31-hopefuls-for-scc-spot>.

Ibid.

The Right Honourable Beverley McLachlin, "The Civilization of Difference" (Remarks delivered at the Lafontaine-Baldwin Symposium, Halifax, 7 March 2003), online: $<$ scc-csc.ca/judges-juges/spe-dis/bm2003-03-07-eng.aspx>. 
“exclusionary thinking" caution provides a useful foundation for the broader arguments this article is drawing upon.

Chief Justice McLachlin notes that Aboriginal Canadians, Chinese immigrants, Black Canadians, and the Jewish community make up part of a "list of racial groups that have suffered exclusion and discrimination." ${ }^{, 50}$ Diversity is an honourable characteristic for the Supreme Court justices to embody, but without mechanisms of accommodation to rectify potential exclusionary thinking, and absent the recognition of substantial inequities that may exist between applicants with significantly different socio-economic, cultural, and political backgrounds, the diversity requirement may do little more than provide a shell game for Indigenous candidates hoping to serve as a justice at the Supreme Court. Whether intentional or not, the presumption that the functional bilingualism and diversity criteria satisfy equal requirements to be met in the 2016 reforms, in application, is not entirely accurate. Below in Part III.C, this internal inconsistency evident in the appointment process is explored further.

\section{FunCtional Bilingualism ANd Diversity}

Functional bilingualism and diversity have been promoted to the Canadian public as two essential requirements at the forefront of attributes a successful appointee to the Supreme Court will exemplify. But there is a palpable concern that diversity is being ranked second to functional bilingualism when both, on their plain reading, basically carry the same weight in the context of the new reforms. This section briefly acknowledges the complexities of functional bilingualism and illustrates the potential for the watering down of diversity in the 2016 reforms when the two requisites are interpreted together.

Sébastien Grammond, before serving as a Federal Court justice, minimized the implication that functional bilingualism may be exclusionary to the potentially diverse candidate. ${ }^{51}$ The "pursuit of diversity is not a reason to ignore an essential requirement for the job," arguably, the new reforms as outlined above quite clearly insist diversity is now an essential requirement of the job. It should be recognized that, despite resting on unnamed "media reports" ${ }^{\prime 3}$ concerning ethnic minorities and acknowledging that they themselves had not performed a survey of Indigenous Judges in Canada, Grammond and Power clarify that it is an "unverified assumption" that ethnic minorities or Indigenous peoples — the presumably diverse contingent — do not speak French. ${ }^{54}$

Grammond and Power also pragmatically discuss a modification to the implementation of the functional bilingualism requirement suggesting that no more than two unilingual justices should serve at the Supreme Court of Canada at one time. ${ }^{55}$ This concession in application would balance the requisites and leaves the door open for an ethnic minority or

Ibid.

Grammond \& Power, supra note 10.

Ibid at 14 .

Ibid.

Ibid.

Ibid. 
Indigenous unilingual candidate to be successfully appointed to the Supreme Court under the diversity requirement, without needing to satisfy functional bilingualism.

David Butt argues that ranking French proficiency above diversity could be perilous, noting that, "[i]f any diversity trait should be emphasized in an era of reconciliation, it should be Indigenous membership on a court imposed by colonizers in 1875." 56

More notably, the 2016 Canada Census recorded over 60 Aboriginal languages that can be grouped into 12 distinct language families. ${ }^{57}$ Surely this is an indicator of the inherent diversity within Indigenous communities and peoples today in Canada. This internal Indigenous cultural diversity is also apparent in the sheer existence of "over 600 First Nations communities," ${ }^{, 5}$ which are culturally unique and dispersed throughout Canada. This illustrates the fallible exercise of trying to rank functional bilingualism above diversity. Qualified Indigenous applicants not only prima facie satisfy as members of the Board's diverse group identified in Part III, they also possess an internally diversified collective of cultures, languages, and geographical experiences that could diversify and enrich the perspectives relied on to make decisions of national importance at the Supreme Court of Canada.

Diversity has been promoted on equal footing with functional bilingualism as one of the two essential requirements a successful Supreme Court appointee will personify. The requirement of functional bilingualism, while not explicitly contradicting the diversity requirement, highlights latent gaps in the rationale of the reforms when the two are interpreted together in the context of an Indigenous candidate. In this era of reconciliation with Indigenous Canadians, a rebalancing of the weight given to certain appointment criteria may be necessary to accommodate the glaring difference in socio-economic and linguistic opportunities afforded to non-Indigenous applicants when compared to those afforded to Indigenous ones.

One argument for this is that the content of the diversity requirement standard leaves much to be desired with respect to the Indigenous candidate, in that the diversity of that group demands constitutional deference. Furthermore, the vast rounding up of Indigenous candidates with numerous others in the diversity category may undermine the special status of Indigenous peoples under section 35 of the Constitution Act, $1982 .{ }^{59}$

How can the Supreme Court ensure Indigenous applicants are diverse enough to be sensitive to the social values of disadvantaged minorities, and reflective of Canadian society, if the selection process makes no obvious concessions to accommodate and reconcile the exclusionary consequences of colonialism that may have negatively impacted those applicants, in turn, giving non-Indigenous appointment hopefuls the advantage of a

Statistics Canada, The Aboriginal Languages of First Nations People, Métis and Inuit, Catalogue No 98-200-X2016022 (Ottawa: Statistics Canada, 2017) at 1, online: <www12.statcan.gc.ca/ censusrecensement/2016/as-sa/98-200-x/2016022/98-200-x2016022-eng.pdf>.

58 Ravina Bains, "Myths and Realities of First Nations Education" (Centre for Aboriginal Policy Studies, August 2014) at 1, online: <fraserinstitute.org/sites/default/files/myths-and-realities-of-first-nationseducation.pdf $>$.

$59 \quad$ Supra note 1. 
qualifying head start? Part IV of this article revisits functional bilingualism, and the requirement is examined in the context of colonialism, reconciliation, French support for the reforms, and critics of the 2016 requirements.

It is critical to note that in Part IV it is not being suggested that reconciliation means the Board is required to guarantee an Indigenous person serve as a justice at the Supreme Court of Canada and the following arguments should not be interpreted thus. The parameters of reconciliation, in its broadest legal and political applications, requires the balancing and the enforcement of both non-Indigenous and Indigenous perspectives and experiences in all levels of Canadian society. The appropriate engagement with Indigenous diversity should embrace accommodation to reflect broader societal and reconciliatory needs and the rectification of Indigenous resources in the first instance; reconciliation is not blanket equality. It is in this context that reconciliation is not being engaged adequately in the new Supreme Court appointment process.

\section{ThE IMPOSITION OF FUNCTIONAL BILINGUALISM}

\section{A. RECONCILIATiON}

Eight years after the enactment of section 35(1) in the 1990 decision R. v. Sparrow ${ }^{60}$ the concept of reconciliation was propelled to the vanguard of Canadian Aboriginal law. ${ }^{61}$ Conspicuously, this meaning of reconciliation does not totally encapsulate the varied and ever-evolving definitions of reconciliation. In its application of reconciliatory principles in the 1996 R. v. Van der Peet ${ }^{62}$ decision, the Supreme Court affirmed and expanded upon Sparrow. "[T] he aboriginal rights recognized and affirmed by s. 35(1) must be directed towards the reconciliation of the pre-existence of aboriginal societies with the sovereignty of the Crown." ${ }^{63}$ In effect, the legal impetus for reconciliation flows from section 35 of the Constitution Act, 1982 and stands for the broad policy objective that Canada is mandated to reconcile the rights and interests of Aboriginal societies with that of non-Aboriginal societies.

The TRC understands responsibility and need for reconciliation at the individual, family, community, business, civic, institutional, and governmental levels: "Reconciliation not only requires apologies, reparations, the relearning of Canada's national history, and public commemoration, but also needs real social, political, and economic change." ${ }^{\text {66 }}$

60 [1990] 1 SCR 1075 [Sparrow].

$61 \quad$ Ibid at 1109 ("federal power must be reconciled with federal duty and the best way to achieve that reconciliation is to demand the justification of any government regulation that infringes upon or denies aboriginal rights").

[1996] 2 SCR 507 at paras 26-47.

Ibid at para 31 .

Rachel Ariss, Clara MacCallum Fraser \& Diba Nazneen Somani, "Crown Policies on the Duty to Consult and Accommodate: Towards Reconciliation?" (2017) 13:1 JSDLP at 12, online: <mcgill.ca/ $\mathrm{mjsdl} /$ files/mjsdl/2_volume_13_ariss.pdf $>$ [footnotes omitted], citing Truth and Reconciliation Commission of Canada, Honouring the Truth, Reconciling for the Future: Summary of the Final Report of the Truth and Reconciliation Commission of Canada (Truth and Reconciliation Commission, 2015) at 238, online: <publications.gc.ca/collections/collection_2015/trc/IR4-7-2015-eng.pdf>. 
Presumably, this "real social, and, political change" would logically extend to Canada's judicial appointments.

The 2005 Mikisew Cree First Nation v. Canada (Minister of Canadian Heritage) ${ }^{65}$ decision's application of the word "peoples"66 may suggest the Supreme Court's "understanding of reconciliation reflects something beyond formal law, something that can guide both legal and social relationship building." reconciliation contains Indigenous and non-Indigenous obligations, and more importantly, participatory rights. Yet, Canada arguably remains entrenched in colonialism. ${ }^{68}$ As such, a venture toward meaningful reconciliation must insist and ensure Canada's institutions and conventions incorporate Indigenous participation and perspectives into the political and legal forefront of Canada now - and into the future - alongside English and French world views.

Ahead of the 2016 Supreme Court of Canada nomination process, there was hope that the new appointee would be Indigenous; otherwise, there was speculation Prime Minister Trudeau would face significant criticisms. ${ }^{69}$ However, a decision appointing an Indigenous, Inuit, or Métis person would have been difficult considering not any of the three final applicants on the Board's shortlist were Indigenous. ${ }^{70}$ This begs the question: Have reforms to the Supreme Court appointment process excluded the Indigenous interest supposedly protected and encouraged under the principles of reconciliation and section 35 ? Is the selection process inconsistent in that it does not recognize the reconciliatory gap being created that calls for diversity of the candidates on one hand, but on the other hand simultaneously omits the Indigenous world view? As a result, is the process denying Indigenous peoples the opportunities to participate fully in the "real social and political change" of Canadian society by ignoring the advantages afforded to qualified nonIndigenous judges?

Non-Indigenous and Indigenous perspectives and interests are to be mutually tied together in Canadian law and policy for reconciliation to be achieved. How is the stringent threshold of French bilingual competence recognizing or affirming the Indigenous Canadian experience at the Supreme Court? Indigenous legal scholars and practitioners have weighed in on these very questions to address the effects of colonialism as they pertain to the functional bilingualism requirement.

To achieve reconciliation - reconciliation that is not a window dressing to perpetuate an assimilationist or colonial agenda - fluency in an Indigenous language should satisfy the functional bilingualism requirement. ${ }^{71}$ Incorporating Indigenous perspectives reasonably requires the transmission of Indigenous ideologies. Those ideologies may only be possible to explain from the starting position, and in the confines, of an Indigenous language.

2005 SCC 69.

Ibid at paras 1, 3-4, 6, 8, 11, 15, 26, 29, 35, 63 .

Ariss, MacCallum Fraser \& Somani, supra note 64 at 12.

See e.g. Andrew Woolford \& Jeff Benvenuto, "Canada and Colonial Genocide" (2015) 17:4 J Genocide Research 373.

Celine Cooper, "Bilingualism, Reconciliation and the Supreme Court," Montreal Gazette (1 January 2018), online: $<$ montrealgazette.com/opinion/celine-cooper-bilingualism-reconciliation-and-the-supreme -court>.

Ibid.

See Russell, supra note 39 at 11-12. 
Conversely, insisting that an Indigenous candidate who does not meet the bilingualism requirement speak an Indigenous language may also be a short-sighted solution.

The loss of Indigenous languages induced by the residential school era in Canada should not inadvertently disqualify a unilingual Indigenous applicant. In that context, there may be a substantive equality argument that bilingualism should not be required for Indigenous candidates at all. ${ }^{72}$ The appointment of an Indigenous unilinguist may be more adequately responsive to reconciliation and the realities of settler colonization as it has impacted generations of potential Indigenous candidates.

John Borrows advocates for an Indigenous appointment to the Supreme Court of Canada as an action that falls within the legal parameters of reconciliation. He believes it "would also be consistent with section 35(1) of the Constitution Act, 1982 and would recognize the unique constitutional status of Aboriginal peoples in Canada," and that "[a]ppointing members of the Supreme Court with Indigenous law experience would increase its competence in strictly legal terms and develop its specific capacity to deal with Aboriginal issues." 73 Borrows is not alone in this position. Larry Chartrand, Lisa Chartrand, Bruce Feldthusen, and Sarah Han argue that preserving an Indigenous seat on the Supreme Court is an important step in ensuring its legitimacy as a multi-juridical institution. ${ }^{74}$

Chartrand, among others, is suggesting that any interpretations of section 35(1) that purposively and generously take into account the perspective of Indigenous peoples, while also accounting for the common law perspective, would be best achieved by Indigenous judges trained in both Indigenous law and the common law. ${ }^{75}$ This suggestion, while important, broadens the argument to include Indigenous law knowledge as additional and potential grounds for an appointment, which goes beyond the scope of this analysis. However, it demonstrates the magnitude of potential accommodation and flexibility that could be included in the appointment process so that the weight of the essential job requirements would be balanced to the benefit of an Indigenous candidate in order to be consistent with reconciliation and section 35. Again, reconciliation in the context of these arguments is contained to the reconciling of perspectives in all areas of Canadian society, and that would reasonably require the promotion of an Indigenous viewpoint and encouragement of Indigenous legal knowledge at the Supreme Court.

The current status of reconciliation in Canada is questionable in that there are criticisms that connect the broader failings of the legal order for Indigenous peoples generally to the achievement of reconciliation. In testimony provided by Jody Wilson-Raybould before the Justice Committee of Canada in February of 2019, speaking about her experience as the former Attorney General of Canada, Wilson-Raybould provided powerful insights into the rule of law and its applications with respect to Indigenous Canadians. ${ }^{76}$ Her statement, in

See Cairns Way, supra note 22 at 26.

John Borrows, Canada's Indigenous Constitution (Toronto: University of Toronto Press, 2010) at 216. Larry Chartrand et al, "Reconciliation and Transformation in Practice: Aboriginal Judicial Appointments to the Supreme Court" (2008) 51:1 Can Public Administration 143 at 150.

Ibid at $149-50$.

Global News Staff, “Jody Wilson-Raybould's Testimony - Read the Full Transcript of Her Opening Remarks,” Global News (27 February 2019), online: < globalnews.ca/tag/jody-wilson-raybould-openingtestimony-transcript/>. 
part, addresses the disparity with the rule of law as it applies to Indigenous persons compared to non-Indigenous persons in Canada.

But my understanding of the rule of law has also been shaped by my experiences as an Indigenous person and as an Indigenous leader. The history of Crown-Indigenous relations in this country includes a history of the rule of law not being respected. Indeed, one of the main reasons for the urgent need for justice and reconciliation today is that, in the history of our country, we have not always upheld foundational values such as the rule of law in relations to Indigenous Peoples. And I have seen the negative impacts for freedom, equality and a just society this can have first-hand. ${ }^{77}$

The preceding quote infers that regardless of the alleged political interference from the Prime Minister's Office with her former duties as the Attorney General — which informs the context behind this powerful statement - justiciable reconciliation demands more than an invitation for Indigenous peoples to apply to the Supreme Court. One of Canada's former central legal actors at the highest level of operations is acknowledging and condemning a deficit in fairness for Indigenous Canadians in the current legal order.

Her comment indicates that reconciliation demands both an Indigenous voice and a nonIndigenous voice in the highest echelons of decision-making to ensure that the Indigenous community is fairly engaged with respect to the rule of law.

More significantly, the deficiencies in the application of the rule of law articulated by an experienced Indigenous Attorney General, a prima facie member of the diversity group and an individual who was directly involved in the 2016 appointment reforms, must be remedied. Freedom, equality, and representational reconciliation demand it, and these inequitable legal deficiencies, as noted by current Member of Parliament (MP) Wilson-Raybould, presently impose deleterious consequences for Indigenous peoples.

The following arguments provide an alternative position on the deficiencies of the judiciary and rely heavily on the opinions of those in support of the ideological foundations of functional bilingualism. They are raised because the criticisms from Indigenous opponents of functional bilingualism are unexpectedly reinforced by the French proponents in that their opinions highlight the existing bilingual deficiencies at the Supreme Court of Canada and support the larger thesis that without accommodation built into the functional bilingualism requirement, both the Indigenous applicants and current Supreme Court justices may fail to satisfy the standard of functional bilingualism required.

\section{B. SUPPORT FOR FUNCTIONAL BILINGUALISM}

Advocates of the functional bilingualism requirement for Supreme Court of Canada appointees reject, in part, the suggestion of unfairness for Indigenous prospects vying for an appointment because of the functional bilingualism criteria. Sébastien Grammond and Mark Power support functional bilingualism as a requirement in the appointment process. ${ }^{78}$ They identify some bilingual capacity issues at the Supreme Court as one sufficient impetus to 
mandate the bilingualism requirement. ${ }^{79}$ They acknowledge that over the last two decades, only one of the nine members of the Supreme Court was unilingual; for them, this suggests that the Board would be able to secure several competently bilingual judges. ${ }^{80}$

Moreover, when comparisons of bilingual accommodation between French and English speakers at the Supreme Court are illuminated, the inadequacy of the former bilingualism requirement becomes palpable. One such example is that English-speaking lawyers have the advantage of oral hearings without translators at the Supreme Court, while French-speaking lawyers have had their oral hearings filtered through translators for the benefit of the justices. ${ }^{81}$ This, the authors suggest, implicitly puts French lawyers at a disadvantage at the Supreme Court.

Grammond and Power raise the issue of "self-correction" at play in pre-functional bilingualism reforms. ${ }^{82}$ They argue that unilingual justices may not have sought clarification where language translation issues arose, and they may have presumed their interpretive errors would be recognized by bilingual colleagues and suggest, as such, unilingual members of the bench may not have appreciated any gaps between the original French arguments and the translation of those arguments. ${ }^{83}$

Justices who cannot meet the functional bilingualism standard may not adequately render decisions adapted to contemporary French society. ${ }^{84}$ Recall that any justice serving today, and appointed before 2016, may fall into this group. The argument is that they may only be capable to serve once they are exposed to the social and political developments through Francophone media or other means.$^{85}$ In other words, an ability to communicate in French would benefit and enable a judge to understand the surrounding culturally relevant policy issues of any decision for Canada's diverse, contemporary society. Even more confounding, when Francophones argue for the bilingualism requirement, acknowledging the impact on Indigenous persons, they are entangled in a complicated self-contradiction.

This argument transfers to the Indigenous candidate seamlessly. If there is no Indigenous justice on the Supreme Court, how will the cultural experience of Indigenous peoples, including a disproportionate experience with colonialism, be understood in the decisions that will apply to Indigenous litigants or lawyers that come before the bench at the Supreme Court? Will reconciliation be considered appropriately - in that policy concerns are identified and understood with cultural competency — when decisions affect Indigenous Canadians?

Grammond and Power raise some persuasive and significant concerns that provide some logical motivations for the new functional bilingualism requirements. What makes their arguments viable to the Indigenous critique is that they support a flexible interpretation of functional bilingualism in that any deficiencies with French competency are mitigated and 
accommodated for the qualified Indigenous applicants, and for the current Anglophone justices.

Echoing Grammond's support for functional bilingualism, former New Brunswick MP Yvon Godin is praising Prime Minister Justin Trudeau's reforms. "Godin, who served as the [New Democratic Party] MP for Acadie-Bathurst for many years, says he wants to see the initiative go further. ${ }^{" 86}$ Graham Fraser, Canada's Commissioner of Official Languages also affirms that functional bilingualism is a long overdue requirement.

\begin{abstract}
I tend to think about whether it is fair to Canadians and their lawyers whose cases are before the Supreme Court. The court system needs to be fair to someone who has argued a case in French at every level in Quebec and now [must] decide whether to plead part of the case in French and part in English, or to trust that the interpreter will grasp the nuances of the argument. Let's ask Sébastien Grammond and Mark Power, who put it in a paper for the Institute of Intergovernmental Relations of Queen's University: "Francophone litigants before the Supreme Court face a challenge that is not shared by their Anglophone counterparts: to attempt to persuade judges who do not understand the language in which arguments are presented." 87
\end{abstract}

Graham Fraser contends that even currently serving Supreme Court justices who would consider themselves functionally bilingual may not meet the functional bilingualism standard.

These arguments are intended to raise the possibility that if justices serving presently at the Supreme Court of Canada are not meeting the bilingual standard expected of new applicants, surely the principles of reconciliation, including accommodation, could bring up the competency of French at the Supreme Court generally. This would facilitate a remedy for the new Indigenous and diverse minority applicants, and presently serving justices. The arguments from proponents indicate that a failure to impose the functional bilingualism requirement without accommodation and flexibility may mark the continuation of an unbalanced and inappropriate level of French competency in a country and judiciary where French is one of two official languages.

There is also the argument that supports functional bilingualism and draws the comparison between the recognition of Quebec's legal system and Indigenous legal systems as grounds for the appointment of an Indigenous judge.

\footnotetext{
Just as the recognition of the civil law of Québec makes it necessary that there be representation of Québec judges specifically on the Supreme Court, so too the recognition of Aboriginal laws and customs as living law in Canada makes Aboriginal representation necessary if the legitimate claim of the Supreme Court to be the final arbiter in cases concerning Aboriginal peoples is to be maintained. ${ }^{88}$
} 2016), online:<cbc.ca/news/canada/new-brunswick/supreme-court-bilingual-justice-yvon-godin-1.370 4626>.

87 Graham Fraser, "In Defence of a Bilingual Supreme Court: Graham Fraser, Canada's Commissioner of Official Languages, on Why Trudeau's Policy on Bilingualism on the Supreme Court Just Makes Sense," Maclean's (2 August 2016), online: <macleans.ca/politics/ottawa/in-defence-of-a-bilingualsupreme-court>, citing Grammond \& Power, supra note 10 at 1. Borrows, supra note 73 at 215 [footnotes omitted]. 
Kayla Cheeke affirms this argument, citing the Reference re Supreme Court Act, ss. 5 and $6 .{ }^{89}$ In part, the Reference SCA determined that reserving Quebecois seats on the Supreme Court of Canada would not only "provide civil law expertise for legal purity and accuracy purposes," but more importantly, "the seats were reserved to ensure that Quebec's legal traditions and social values were represented on the Court, thereby enhancing the confidence of Quebec citizens." ${ }^{90}$ Cheeke recognizes that by having an Indigenous justice at the Supreme Court of Canada, as apparent with the Francophone appointments, Indigenous peoples' confidence in the judicial system could be strengthened by ensuring that their social values and traditions are represented, and that they may see themselves positioned on the highest Court in Canada. ${ }^{91}$

The following opinions on functional bilingualism as a requirement for an appointment to the Supreme Court of Canada engage a critical anti-colonial lens from a primarily Indigenous contingent of critics. The main objections rest in the omission of accommodation of colonial circumstances that may disproportionately disadvantage an Indigenous candidate, and the idea that an Indigenous perspective will benefit the Supreme Court.

\section{FunCtional Bilingualism CRitics}

Critics of the functional bilingualism requirement consider it blatantly exclusionary. NDP MP Roméo Saganash and Canadian lawyer and NDP MP Jagmeet Singh consider the idea of Supreme Court candidates being bilingual a colonialist one. ${ }^{92}$ Indigenous leaders including Senator Murray Sinclair, Chief Perry Bellegarde, and former Indigenous Bar Association President Koren Lightning-Earle echo this sentiment. ${ }^{93}$

John Borrows submits that "[t]he most important reason for appointing people to the bench who have knowledge of Indigenous legal traditions is that they bring new ideas to their task." "94 "A change of ideas when exercising judgment will bring broader reform than almost any other initiative." 95 He prioritizes the Indigenous experience, consistent with the principles of section 35(1) and reconciliation, ahead of the functional bilingualism requirement.

David Butt argues that a mandatory French proficiency functional bilingualism requirement rewards "those born into francophone or bilingual families, or born to anglophone parents who enroll their kids in French immersion." 96 He draws his criticism from the impact functional bilingualism has had on Judge Harry LaForme. Judge LaForme was born on a Crown reservation but was never given an opportunity to learn French. $\mathrm{He}$

2014 SCC 21 [Reference SCA].

Kayla Cheeke, "Reconciling Crown and Indigenous Legal Orders: The Reciprocal Benefits of Reserving an Indigenous Seat on the Supreme Court of Canada" (2017) 22 Appeal 97 at 104, citing Reference SCA, ibid at para 19.

Cheeke, ibid.

Maxime St-Hilaire et al, "The False Francophone-Indigenous Conflict over SCC Judges," online: $<$ policyoptions.irpp.org/magazines/december-2017/the-false-francophone-indigenous-conflict-over-sccjudges $/>$.

Ibid.

Supra note 73 at 217.

Ibid.

Supra note 40. 
would be potentially barred from serving on the Supreme Court of Canada. ${ }^{97}$ These barriers are easy to imagine when one turns their mind to the legacy of Canadian residential schools, the Sixties Scoop, and the cumulative impacts of colonialism.

Adding insult to injury, in 2016, in her capacity as Minister of Justice, Jody WilsonRaybould made what can only be described as an inaccurate remark concerning the functional bilingualism requirement. She wanted "to encourage all of those individuals out there that meet the statutory requirements ... to brush up on their French if they are wanting to apply to be the next Supreme Court justice. ${ }^{98}$ This comment not only conceals the high standard now expected of a functionally bilingual candidate as identified in Part II, but this statement is a reductive account of the colonial complexities an Indigenous candidate may face when trying to access colonial languages because they may have been excluded from opportunities in formal education. Her comment also fails to account for the over sixty languages potentially spoken by Indigenous applicants to the Supreme Court of Canada. Chief Perry Bellegarde would interject here that Canada was not founded in only English and French. $^{99}$

In consideration of the Francophone and functional bilingualism proponents, the functional bilingualism requirement could be interpreted as a necessary extension of our laws surrounding official language recognition already in place. Yet, in consideration of the principles of reconciliation contextualized in this analysis, and in contemplation of the anticolonial and diverse criticisms, functional bilingualism operates counterintuitively against the principles necessary for Indigenous-Canadian reconciliation. The functional bilingualism requirement, by omission of accommodation, seems to implicitly require more than an ability to speak French and English for those applicants who may feel excluded by its imposition.

Part IV of this article has sought to identify an inherent consequence of the functional bilingualism requirement, that is, the impossibly colonial implications of mandating a functional bilingualism requirement on an otherwise qualified, competent, and possibly Indigenous unilingual applicant. Moreover, the bilingual competency at the Supreme Court of Canada may not presently meet the high standard expected of new applicants since 2016, which lends support to the Indigenous critic who would suggest that there must be accommodations in place for Indigenous applicants to meet the qualifications. Moreover, these accommodations would then have the additional benefit of remedying any deficiencies in play for the Anglophone justices serving on the bench today. In consideration of the above analyses, Part V offers a synthesis of the issues, and presents recommendations for the future.

\section{ANALYSIS AND RECOMMENDATIONS}

Canada is a country of two official languages, and there are numerous constitutional and Charter protections afforded to both French and English languages legally, politically, and

$97 \quad$ Ibid.

$98 \quad$ Peter Zimonjic, "Functionally Bilingual Requirement for Supreme Court Justices Here to Stay, Says Wilson-Raybould," CBC News (24 October 2016), online: <cbc.ca/news/politics/rowe-campbell-wilsonraybould-supreme-court-1.3819210>.

99 Kristy Kirkup, "Top Court's Bilingual Rule a Barrier to Indigenous Judges: Sinclair, Bellegarde," The Globe and Mail (22 September 2016), online: <theglobeandmail.com/news/national/supreme-courtsbilingual-requirement-unfair-sinclair-bellegarde/article32011596>. 
in the judiciary. This provides strong evidence for the functional bilingualism requirement in that any vulnerabilities it raises should not outweigh the potential benefits in consideration of existing laws and language conventions. Uniformity and equalization for both French and English languages at the Supreme Court can ensure a standardization and competence that has not been achieved at the Supreme Court of Canada before, and may now become a reality for French litigants, counsel, and justices.

However, this article would strongly caution against this narrow and oversimplified reading of the application of functional bilingualism. Functional bilingualism fits into the existing foundation of Canada's constitutional landscape, but automatic and deferential allegiance to the functional bilingualism requirement should be discouraged. The functional bilingualism requirement should stand, with the important caveat that Indigenous persons are assessed and evaluated with an advantage in the scoring of their appointment applications.

To ensure the French competency of an otherwise non-functionally bilingual appointee - or current member of the bench - there must be accommodations in place through the Board and the OCFJA to remedy a lack of sophisticated proficiency in both official languages. This would afford applicants the opportunity to meet the requirements after they are appointed, with accommodation through language training.

This alternative resolution would be consistent with the principles of reconciliation in the context described above. Accommodating an otherwise qualified Indigenous person to serve at the Supreme Court, so they may meet the functional bilingualism requirement, would operate as a sort of distant cousin to affirmative action with respect to an equal opportunity remedy in consideration of colonialism. ${ }^{100}$ As noted earlier, this kind of accommodation would also assist any current justices who do not meet the standard of functional bilingualism implemented in the 2016 reforms.

The implementation of functional bilingualism is grounded in solid constitutional rationales and should not be eliminated if Indigenous applicants and other diverse applicants are assessed with an automatic advantage to offset the potential depreciation in their scoring that may be a result of their inadequate bilingualism proficiency. To do so would recognize the following:

1. There needs to be an Indigenous justice on the Supreme Court bench because, as this article has identified, Canada's colonial exclusionary past and reconciliatory focused future demands it.

2. The failure of an Indigenous applicant to meet the functional bilingualism requirement should not disqualify their application, and they should remain in the competition if they either satisfy the diversity requirement or speak an Indigenous language.

Girardeau A Spann, "Affirmative Action and Discrimination" (1995) 39:1 How LJ 1 at 5 (affirmative action has been defined as "the race-conscious allocation of resources motivated by an intent to benefit racial minorities"). 
3. In cases like Reference SCA that recognize Quebec's civil law and socio-legal traditions, and for the same reasons Quebec is guaranteed participatory rights, access to serving on the Supreme Court should be a right of otherwise qualified Indigenous candidates notwithstanding the functional bilingualism requirement.

The exclusion of diverse candidates from Indigenous and minority groups without any built-in accommodation in the appointment selection reform procedures, especially if an Indigenous applicant has been excluded from achieving bilingual status as a result of the Canadian Federal Government's colonial law and policies, is indefensible.

\section{CONCLUSION}

The requirement of functional bilingualism in the Supreme Court of Canada appointment selection process was implemented by the Federal Government in 2016, but the House of Commons defeated the private member's bill seeking to enshrine the functional bilingualism requirement in law. ${ }^{101}$ The impact of the new requirements have sparked controversy over the new Board, functional bilingualism and diversity requirements, and the impact these criteria impose for applicants from the diversity contingent, in particular, Indigenous judges.

This article has identified reforms to the appointment process, examined the scope and content of the new Advisory Board and functional bilingualism, acknowledged the moderately arbitrary and potentially exclusionary diversity requirements when compared to the functional bilingualism criteria, noted the inconsistencies with functional bilingualism in reconciling the perspectives and interests of non-Indigenous and Indigenous Canadians, addressed functional bilingualism's supporters who identified deficiencies with bilingualism at the Supreme Court of Canada as the impetus for functional bilingualism, and distinguished the anti-colonial critics of functional bilingualism.

The requirement of functional bilingualism to be considered for an appointment to the Supreme Court raises potential barriers for Indigenous candidates from serving despite functional bilingualism's consistency with Canada's two official languages. The requirement should stand, but not in a vacuum. Accommodation is integral to reconciliation. By affording a qualified, diverse member from Canada's marginalized Indigenous communities the opportunity to become functionally bilingual in order to serve as a Supreme Court justice through any necessary accommodations would provide them with the ability to interpret and apply the law as it affects all Canadians. This would be a remarkable gesture signifying Canada's willingness to accept responsibility for colonial inequalities implemented by the Crown, and would be central to the experience of otherwise qualified minority and Indigenous applicants. 